\title{
https://doi.org/10.30853/filnauki.2020.2.19
}

\section{Го Линь}

Деривационный потенциал синонимичных глаголов ощущать и чувствовать:

\section{сравнительный анализ}

Статья посвящена проблеме функционального разграничения синонимичных дейктических глаголов 'ощущать' и 'чувствовать'. Путѐм сопоставления словообразовательных гнезд э тих слов и контекстуального анализа речевых употреблений их производных выявлены корреляции между лексико-семантическими вариантами (ЛСВ) глаголов и их дериватами. Сделан вывод о более высокой функциональности второй лексемы (23 и 45 дериватов соответственно). Установлено, что у глагола 'чувствовать' по количеству дериватов доминирует ЛСВ 'испытывать эмоциональное состояние', тогда как у глагола 'ощущать' наиболее продуктивен ЛСВ 'понимать интуитивно'.

Адрес статьи: www.gramota.net/materials/2/2020/2/19.html

\section{Источник}

Филологические науки. Вопросы теории и практики

Тамбов: Грамота, 2020. Том 13. Выпуск 2. С. 101-107. ISSN 1997-2911.

Адрес журнала: www.gramota.net/editions/2.html

Содержание данного номера журнала: www.gramota.net/materials/2/2020/2/

\section{() Издательство "Грамота"}

Информация о возможности публикации статей в журнале размещена на Интернет сайте издательства: www.gramota.net Вопросы, связанные с публикациями научных материалов, редакция просит направлять на адрес: phil@gramota.net 


\section{Русский язык}

\section{Russian Language}

УДК 811.161 .1

https://doi.org/10.30853/filnauki.2020.2.19

Дата поступления рукописи: 10.01.2020

Статья посвящена проблеме функиионального разграничения синонимичных дейктических глаголов 'ощущзать' $и$ 'чувствовать'. Путём сопоставления словообразовательных гнезд этих слов и контекстуального анализа речевых употреблений их производных выявлены корреляции между лексико-семантическими вариантами (ЛСВ) глаголов и их дериватами. Сделан вывод о более высокой функииональности второй лексемь (23 и 45 дериватов соответственно). Установлено, что у глагола 'чувствовать' по количеству дериватов доминирует ЛСВ 'испьтывать эмоциональное состояние', тогда как у глагола 'ощущать' наиболее продуктивен ЛСВ 'понимать интуитивно'.

Ключевые слова и фразы: лексические синонимы; словообразовательная парадигма; словообразовательное гнездо; деривационный потенциал; лексико-семантический вариант.

\section{Го Линь}

Казанский (Приволжский) федеральный университет guolin315@mail.ru

\section{Деривационный потенциал \\ синонимичных глаголов ошуццатв и чувствовать: сравнительный анализ}

В современном русском языке глаголы ощущать и чувствовать синонимичны и семантически трудноразличимы, что привлекает внимание изучающих русский язык как иностранный в аспекте их функционального разграничения. Выявлению лексико-семантической специфики этих синонимов посвящены наши статьи $[1 ; 2]$. Дейктическая природа данных лексем позволяет им выполнять функцию указания на состояния живого существа самого широкого спектра (чувственное восприятие, физическое и эмоциональное состояние, ментальное состояние), в чём и заключается их семантическое сходство. При этом лишь лексеме чувствовать свойственна способность описывать две специфические ситуации: 1) 'быть способным к эстетическому восприятию', напр.: Яванцыь тонко чувствуют ивет, форму, умеют находить красоту в проcmoте (В. Овчинников. Своими глазами) [9]; 2) 'быть способным к пониманию другого', напр.: Классики тоже подчеркивают, что психиатр может рассчитывать на успех лечения, лишь если он до глубинь души задет болезнью пациента. <..> Во время сеанса я чувствую больного как бы изнутри, вижу все нюансы его патологии (О. Грибков. О чем говорят маски) [Там же].

Для более тонкого разграничения полифункциональных языковых единиц, обладающих чрезвычайной семантической близостью, анализа их лексической семантики оказывается недостаточно, поскольку остается невыявленной функционально-семантическая доминанта каждой из них. Актуальность настоящей работы, обусловленная, прежде всего, антропоцентрической релевантностью исследуемых глаголов, их способностью участвовать в описании любых внутренних состояний человека, аргументируется, кроме того, необходимостью всестороннего исследования синонимичных лексем такого типа, в единстве их парадигматических, синтагматических и деривационных свойств. Так, в частности, рассуждая о разграничении семантически близких, в том числе абсолютных, синонимов, С. Д. Кацнельсон акцентировал внимание на их деривационных свойствах, поскольку у таких лексем «прослеживаются дополнительные оттенки, связанные с происхождением слов и их словообразовательными связями» [6, с. 74].

Деривационные связи интересующих нас глаголов, наиболее полно отраженные в их словообразовательных гнездах, являются двусторонне значимыми: в аспектах словообразовательного анализа и словообразовательного синтеза. С одной стороны, словообразовательное гнездо строится на иерархически упорядоченных отношениях между производящими и производными словами, обнаруживаемых при анализе их синхронической деривационной истории [10, с. 26-27]. Представляя «несомненный интерес как комплексная единица динамического словообразования» [3, с. 9], словообразовательное гнездо позволяет частично 
прояснить формально-семантические истоки исторически производных синонимов, каковыми являются также глаголы ощущать и чувствовать. С другой стороны, глаголы ощущать и чувствовать сами выступают в качестве производящих для целого ряда производных слов; их словообразовательные парадигмы рассматриваются в качестве механизма «формирования производной лексики из того семантического потенциала, который содержится в производящем слове» [13, с. 99-100], всецело выявляя этот потенциал.

Цель настоящего исследования заключается в сравнении направлений семантической эволюции рассматриваемых синонимов путём анализа их словообразовательных связей. Достижение этой цели требует решения следующих задач: рассмотреть структуру и семантику словообразовательной парадигмы (далее - СП) глаголов ощущцать и чувствовать; путём разноаспектного функционального анализа производных слов в составе словообразовательных гнёзд (далее - СГ) сравниваемых лексем установить корреляции между конкретными лексико-семантическими вариантами глаголов (далее - ЛСВ) и их дериватами, поскольку, как известно, «если исходное слово многозначно, то производные могут группироваться вокруг разных его значений» $[15$, т. 1 , с. 45]; на основе полученных данных сделать заключение о доминирующем векторе функционально-семантического развития сопоставляемых лексем в современном русском языке. Для решения обозначенных задач были применены соответствующие методы исследования: анализ словарных дефиниций, словообразовательный анализ и контекстуальный анализ.

Научная новизна исследования состоит в том, что данная работа представляет собой первый опыт комплексного сопоставительного анализа дейктических синонимов с применением функционального подхода. Полученные данные проливают свет на содержание важных концептов русской языковой картины мира ОЩУЩЕНИЕ и ЧУВСТВО, проясняя место и роль анализируемых глаголов в ментальном лексиконе носителей русского языка. Практическая значимость статьи связана с возможностью использования полученных результатов при работе с трудноразличимыми функциональными синонимами русского языка в иностранной аудитории.

В качестве лексикографических источников исследования использованы Словообразовательный словарь русского языка А. Н. Тихонова [15], Русский семантический словарь под редакцией Н. Ю. Шведовой [12], четырехтомный Толковый словарь русского языка под ред. А. П. Евгеньевой [14]; контекстуальный анализ производных единиц осуществлялся на основе материалов Национального корпуса русского языка [9].

По данным словаря А. Н. Тихонова, глагол ощутить вкупе со своим грамматическим коррелятом ощущзать формирует в современном русском языке СГ, включающее 23 деривата, пять из которых характеризуются непосредственной глагольной мотивированностью: ощущение, ощутимый, ощутительный, ощущзаться, предощущать ${ }^{1}$. Они образуют конкретную СП анализируемого глагола и являются наиболее ярким воплощением его деривационного потенциала.

В их числе - существительное ощущение, представленное в словарях как многозначное, ср.: «1. действие по знач. глаг. ощутить - ощущать»; «2. результат воздействия явлений объективного мира на органы чувств человека»; «3. состояние, впечатление, чувство, вызванное чем-л., испытываемое кем-л.» [14, т. 2, с. 736]. В своём первом значении слово ощущеене является синтаксическим дериватом производящего глагола. Второе и третье значения отражают лексико-семантическую специфику этого существительного, которую оно приобрело как единица лексической системы.

Прилагательные ощутимый и ощутительный, образованные с помощью суффиксов -им- в значении «возможность, допустимость действия или состояния» [5, с. 188] и -тельн- с более общим значением «признак или свойство, характеризующееся тем, что названо мотивирующим словом» [Там же, с. 216], являются семантическими эквивалентами. Ср.: ощутительный - «1. такой, который ощущается, чувствуется. Дамы отправились в гостиную, где запах “гвоздичной” сделался ещзе более ощутителен (Григорович. Лотерейный бал)»; «2. перен. Значительный по своему проявлению, заставляющий считаться с собой, чувствительный. Ощутительный недостаток. Ощутительная разница. Ощутительное явление» [14, т. 2, с. 736]; ощутимый«то же, что ощутительный» [Там же]. Будучи устаревшим, слово ощутительный относится к пассивному фонду современного русского языка.

В данной СП представлены два глагольных деривата - ощущаться и предощущать. У постфиксального глагола ощущаться, помимо грамматического значения страдательного залога, зафиксировано также значение «быть заметным, чувствоваться» [Там же]. Префиксальный производный глагол предощущать обладает семантикой временной модификации, выражая значение «заранее ощущать, заранее чувствовать» [Там же, т. 3, с. 368].

От производных слов первой ступени деривации в исследуемом СГ образованы следующие лексемы: 1) на базе существительного ощущение возникли слова ощущеньице, жизнеощущение, мироощущение, самоощущение, ияветоощущение; 2) к прилагательному ощутимый восходят неощутимый, ощутимо, неощутимо, ощутимость, неощутимость; 3) словом ощутительный прямо или опосредованно мотивированы производные неощутительный, ощутительно, неощутительно, ощутительность, неощутительность; 4) в число дериватов глагола предощущать входят слова предощущцаться и предощущение.

Далее на основе результатов словообразовательного анализа производных слов данного гнезда и контекстуального анализа фрагментов текстов из Национального корпуса русского языка с каждым из этих дериватов была установлена мотивационная соотнесённость между конкретными ЛСВ исходного слова ощущать и элементами его СГ.

\footnotetext{
${ }^{1}$ В качестве вершины данного СГ представлен глагол совершенного вида, однако очевидно, что все производные единицы гнезда мотивационно соотносятся с обоими видовыми коррелятами.
} 
С ЛСВ ‘воспринимать органами чувств’ соотносится 16 дериватов, из которых существительное изветоощущение восходит лишь к данному ЛСВ, ср.: Верхним порогом цветоощущения является та яркость света, которая «ослепляет» глаз (С. Рубинштейн. Основы общей психологии) [9].

С ЛСВ ‘испытывать какое-л. физическое состояние' деривационно коррелирует также 16 слов. Состав производных данного ряда отличается от предыдущей группы существительным самоощущение, ср.: $B$ шуточном определении «сын моего отияа, но мне не брат» содержится гораздо больше истинь, чем в элементарном телесном самооцуцении (А. Секацкий. Истоки современной политики) [Там же]. Этот дериват выявляет, кроме того, соотнесённость с ЛСВ, описывающими эмоциональное и ментальное (моральное) состояния, ср.: На бумагу просилось грустное самоощущение (Д. Данин. Нильс Бор) [Там же]; Бессмысленно пытаться насильно изменить самоощущение народа - еще час не пришел (В. Персиков. Такая музыка им не нужна) [Там же]. В целом вокруг ЛСВ 'испытывать какое-л. эмоциональное или душевное состояние, чувство' группируется 16 дериватов.

К ЛСВ ‘понимать сознанием, интуитивно’ деривационно восходит 21 дериват, в их числе мотивированы лишь данным ЛСВ следующие производные:

- жизнеощущение, ср.: Символизм есть больше, чем философское учение, он есть целое жизнеощущение, onыm (Л. Гоготишвили. Символизм Вяч. Иванова на фоне имяславия) [Там же];

- мироощущение, ср.: ...литература рассматривается как «учебник жизни», как источник моральных ценностей, как способ передачи из поколения в поколение некоего «национального мироощущения» (М. Арапов. Когда текст обретает смысл) [Там же];

предошущать и его дериваты предошущзение и предошущаться, ср.: Те, у кого этот зазор (по генетическим причинам) слишком велик, еще не успевают переварить первую часть шутки, когда приходит вторая, а те, у кого он слишком мал, очень быстро предощущают, что сейчас должно последовать некое смешное опровержение сказанного... (Анатолий Лефко. Могут ли компьютеры смеяться?) [Там же].

Обобщим результаты осуществлённого комплексного лексико-словообразовательного и контекстуального анализа элементов СГ глагола ощущать. Такие элементы СП лексемы ощущать, как ощущение (и его дериват ощущеньище), ощущаться, ощутимый (и его дериваты ощутимо, ощутимость, неощутимый, неощутимо, неощутимость), ощутительный (и его дериваты ощутительно, ощутительность, неощутительный, неощутительно, неощутительность), соотносятся с каждым ЛСВ исходного глагола, тогда как префиксальный глагол предощущать (и его дериваты предощущаться, предощущеене) мотивационно связан лишь с ЛСВ 'понимать интуитивно, осознавать'. Выявлены специфические смысловые корреляции между некоторыми единицами СГ глагола ощущать, находящимися на второй и третьей ступенях деривации, и отдельными ЛСВ исходного глагола: дериват самоощущение мотивирован тремя ЛСВ, описывающими ситуации пребывания в физическом, эмоциональном и ментальном состояниях; производные жизнеощущение, мироощущение, предощущать и предощущение обнаруживают мотивационную связь лишь с ЛСВ 'понимать сознанием, интуитивно'; дериват ицветоощущение соотносится только с ЛСВ 'воспринимать органами чувств'. Сказанное позволяет сделать заключение о наибольшей словообразовательной продуктивности ЛСВ глагола ощущать 'понимать интуитивно, осознавать' (21 дериват на фоне шестнадцати производных у каждого из трёх других ЛСВ) и, соответственно, о его наиболее развитом семантическом потенциале.

Глагол чувствовать занимает позицию, соответствующую второй ступени деривации в СГ исходного слова чуять (81 ед.), он образован от существительного чувство. Однако, учитывая абсолютную симметричность семантических отношений в словообразовательных парах ощущать - ощущение и чувствовать чувство, правомерно констатировать однонаправленность их мотивационных векторов, объясняемую развитием в современном русском языке обратной соотнесенности.

В качестве вершины довольно обширного подгнезда глагол чувствовать обладает 45 дериватами, из которых 14 производных - чувствоваться, чувствование, чувствилище, самочувствие, чувствительный, восчувствовать, дочувствовать, перечувствовать, почувствовать, предчувствовать, прочувствовать, вчувствоваться, очувствоваться и расчувствоваться - образованы непосредственно от данного глагола и составляют его СП. Исходя из частеречной принадлежности производных, в ней можно выделить три блока: субстантивный, адъективный и глагольный.

1. Субстантивный блок сформирован путем суффиксации (чувствование, чувствилище) и сложения (самочувствие). В большинстве толковых словарей современного русского языка дериват чувствование отсутствует вообще; в четырехтомном Толковом словаре русского языка под ред. А. П. Евгеньевой его значение толкуется следующим образом: «1. состояние по знач. гл. чувствовать. [Варламов] не знал, как надо сказать, но чувствовал - и говорил так, как чувствовал. А чувствование его на сцене было так безбрежно, так широко и глубоко, что... проникало в душу любого... Горин-Горяйнов, Кулисы»; «2. устар. то же, что ч у в с т в о (в 4 и 7 знач.)» [14, т. 4, с. 689]. Четвертое и седьмое значения слова чувство таковы: «4. внутреннее психическое состояние человека, его душевное переживание \| внутреннее волнение, душевный подъем, порыв»; «7. любовь, испытываемая кем-л. к кому-л.» [Там же]. Все контексты, иллюстрирующие в словарных статьях функционирование субстантива чувствование в качестве синтаксического деривата производящего глагола чувствовать, свидетельствуют об архаизации этого слова в современном русском языке.

Имя существительное чувствилище, также снабжённое в словарях пометой «устар.», получило следующее толкование: «То, что способно воспринимать чувства, впечатления из окружающей среды» [Там же, с. 688]. Словообразовательное значение (далее - С3) дериватов с суффиксом -лищ- - «место действия, само действие или учреждение, связанные с действием, названным мотивирующим глаголом» [5, с. 255]. В ситуации, 
описываемой в приведённом ниже фрагменте текста, слово чувствилище играет роль семантического актанта Инструмент, с помощью которого Субъект воспринимает чувства или впечатления, ср.: Лермонтов понимал, что если он хочет сохранить своё творческое я, то не надо идти в кабалу к жизни всем своим чувствилищем (И. Анненский. Вторая книга отражений) [9].

Дериват самочувствие имеет значение «общее физическое и нравственное состояние человека, зависящее от его здоровья и настроения в данный момент» [14, т. 4, с. 25]. В приведённой формулировке содержится прямое указание на соотнесённость этого производного с двумя ЛСВ глагола чувствовать, описывающими физическое и эмоциональное состояния.

2. Адъективный блок представлен единственным суффиксальным дериватом чувствительный, который обладает следующими значениями: «1. Способный живо чувствовать, воспринимать, впечатлительный. 2. Исполненный глубокого чувства, сердечности || Трогательный, сентиментальный. 3. Способный воспринимать раздражения || Обладающий повышенной способностью воспринимать физические раздражения. 4. Способный воспринимать, фиксировать самые незначительные внешние влияния, воздействия и т.п. ॥ Способный изменять, утрачивать свои свойства под влиянием воздействий внешней среды, изменения каких-л. условий || Значительный по своему проявлению, способный повлиять, повредить и т.п.» [Там же, с. 688]. В этом объемном толковании обозначена способность данного слова к отражению всех видов внутреннего состояния человека, при описании которых используется дейктический глагол чувствовать: чувственного восприятия, физического, эмоционального и ментального состояний.

3. Глагольный блок СП лексемы чувствовать является самым обширным и представлен префиксальными, конфиксальными и постфиксальными дериватами.

С помощью префиксов образовано шесть глаголов: восчувствовать, дочувствовать, перечувствовать, почувствовать, предчувствовать, прочувствовать.

Толкование глагола почувствовать представлено в четырехтомном Толковом словаре русского языка в следующей формулировке: «сов. $к$ чувствовать». Ю. С. Маслов, характеризовавший глагольные пары типа любить - полюбить, чувствовать - почувствовать в формальном отношении как «морфологически нормальные дублеты», утверждал тем не менее, что «столь различные по своему лексическому значению глаголы, как любить и полюбить (= начать любить), несомненно надлежало бы рассматривать не как грамматическую пару, а как два непарных “недостаточных” глагола» [8, с. 52]. Исходя из этого, правомерно сделать заключение о наличии у этого приставочного глагола семантики начального предела (испытывать состояние с акцентом на его исходной точке).

Все глагольные дериваты, кроме лексемы предчувствовать, относятся к совершенному виду. Глагол предчувствовать, образованный с помощью префикса пред-, обозначающего 'предварительность, заблаговременность действия’, выражает лексическое значение «в душе ожидать чего-н.» [12, с. 256]. В данном толковании сделан акцент на связи анализируемого деривата с семантикой «душевного», то есть эмоционального, состояния.

Глагол восчувствовать является устаревшим. Он относится к высокой лексике русского языка, что связано с его принадлежностью к словообразовательному типу глаголов со стилистически маркированным префиксом вос-, выражающим значение начала «в сплаве с семами интенсивности, внезапности, экспрессивности» [7, с. 32]. Словарное толкование этого производного - «почувствовать, начать испытывать какое-н. чувство, эмоциональное состояние» $[12$, с. 256] - не допускает сомнений в его семантической связи с ЛСВ глагола чувствовать, описывающим ситуацию эмоционального состояния.

Слово дочувствовать толкуется как «прочувствовать что-либо до конца, полностью» [4], что указывает на наличие в его лексическом значении словообразовательной семантики финитивности, которая сочетается в данном случае с семами 'предел' и 'исчерпанность'. Этот глагол зафиксирован только в одном толковом словаре, он низкочастотен (10 вхождений в Национальном корпусе русского языка) и в художественных текстах практически всегда нуждается в актуализации словообразовательной структуры, используясь в одном ряду с глаголами того же словообразовательного типа, например: Прежде чем погрузиться в абсолютное небытие, нужно додумать, доделать, дочувствовать, допережить ... (И. Бахтина. По пути в никуда) [9].

Префиксальный дериват прочувствовать в составе СП производящего глагола входит в число средств выражения С3 'степень интенсивности действия'. Словарная дефиниция этого слова «глубоко поняв, проникнуть чувством в смысл чего-н.; пережить, испытать какое-н. чувство» [12, с. 256] позволяет говорить о его мотивационной связи с двумя ЛСВ производящего глагола чувствовать, описывающими ситуации эмоционального состояния и ментального состояния. Лексема перечувствовать имеет значение «эмоционально прочувствовать многое» [Там же]. Этот дериват соотносится с ЛСВ “испытывать какое-либо душевное состояние, эмоцию, чувство’ глагола чувствовать, выражая объектно-распределительное значение. Более частотное по сравнению с глаголом дочувствовать, это производное тоже часто встречается в одном контексте с другими глаголами данного словообразовательного типа, ср.: Может, именно этот тяжельй период в жизни заставил ее передумать, перечувствовать, перерешить многое (Э. Рязанов. Подведенные итоги) [9].

Три глагольных элемента СП глагола чувствовать образованы путём конфиксации: вчувствоваться, очувствоваться, расчувствоваться.

Глагол расчувствоваться в современном русском языке обладает разговорной маркированностью и обозначает «прийти в умиление; растрогаться» [14, т. 2, с. 683]. Конфикс рас-...-ся в его составе формирует С3 «достигнуть большой интенсивности в совершении действия, которое названо мотивирующим глаголом» [5, с. 436]. Этот дериват семантически восходит к ЛСВ производящего чувствовать 'испытывать какое-либо душевное состояние, эмоцию, чувство'. 
Конфикс в-..-ся, обладающий семантикой интенсивности (С3 «углубиться во что-л.» [Там же, с. 88]), образует глагол совершенного вида со значением «чувством понять, вникнуть во что-л.» [14, т. 1, с. 243], что указывает на его соотнесённость с двумя ЛСВ производящего глагола: 'испытывать эмоциональное состояние' и 'понимать интуитивно'.

Лексема очувствоваться в словарях современного русского языка характеризуется как устаревшая и просторечная единица со значением «прийти в себя, в сознание» [Там же, т. 2, с. 734]. Глаголы с конфиксом $0-\ldots$-ся выражают С3 'прийти в норму при помощи действия, выраженного производящей основой' [11] (ср. одуматься). Через производящее слово чувствовать этот конфиксальный дериват репрезентирует семантическую связь с существительным чувство во втором значении «состояние, в котором человек способен сознавать окружающее» [14, т. 4, с. 689], используемым при описании ситуаций ментального состояния.

Постфиксальным способом на базе лексемы чувствовать образован глагол чувствоваться, который толкуется в словарях следующим образом: «1. быть заметным, ощутимым для кого-л. (об ощущениях, физических состояниях и т.п.)... $\|$ быть доступным обонянию, зрению и т.п., восприниматься органами чувств»; «2. быть заметным, доступным наблюдению \| предугадываться, ощущаться интуитивно»; «3. сказываться, проявляться»; «4. страд. к чувствовать» [Там же, с. 689-690]. Как видим, словарное толкование допускает вывод о деривационной связи данного производного с каждым ЛСВ производящего глагола чувствовать.

Следующий этап нашей работы направлен на выявление менее очевидных мотивационных корреляций между единицами СГ глагола чувствовать, находящимися за рамками его словообразовательной парадигмы, и конкретными ЛСВ производящего. Решение этой задачи потребовало последовательного сочетания словообразовательного анализа с контекстуальным, дав возможность дополнить итоги первого этапа работы новыми либо уточнёнными данными о деривационной и функциональной продуктивности отдельных ЛСВ анализируемого глагола.

Так, установлено, что с ЛСВ глагола чувствовать 'воспринимать органами чувств' деривационно соотносится 23 элемента СГ, большинство из которых (17 ед.) образованы от прилагательного чувствительный. Такие дериваты, как светочувствительный, светочувствительность, пенициллиночувствительный, характеризуются значением 'способность воспринимать физиологически, в том числе через какой-н. канал', ср.: У первых многоклеточных животных органы зрения были крайне примитивны. Так, у многих морских звёзд по всей поверхности тела разбросаны отдельные светочувствительные клетки (А. Зайцев. Загадки эволюции: краткая история глаза) [9]. Сложные прилагательные и их синтаксические дериваты цветочувствительный, цветочувствительность, высокочувствительный, радиочувствительность, словообразовательная семантика которых осложнена когнитивной метафорой, используются для описания свойства или функции определенных приборов и веществ, ср.: Специальные высокочувствительные магнитометры и детекторы искали места с повышенным содержанием металла (Р. Темиргалеев. Сокровища под парусами) [Там же].

К ЛСВ 'испытывать какое-л. физическое состояние' семантически восходит 18 производных единиц, каждая из которых имеет мотивационные связи с какими-либо другими ЛСВ производящего глагола.

ЛСВ ‘испытывать какое-л. эмоциональное, душевное состояние и чувство’ семантически объединяет 37 дериватов, для пяти из которых данная мотивационная связь является единственной: это прилагательное пречувствительный с семантикой интенсивности признака и его дериват пречувствительно, ср.:- Весь он у меня, братеи, в мать пошел: умная ведь она у меня была, но тоже этакая пречувствительная и претревожнная! (А. Писемский. Люди сороковых годов) [Там же]; префиксальный глагол перечувствовать и его дериват перечувствоваться, ср.: Юрий Юрьевич к уроку покуда готовился, много чего пережил, о многом подумал, многое перечувствовал... (С. Залыгин. Уроки правнука Вовки) [Там же]; конфиксальный глагол расчувствоваться, ср.: ...Таня вдруг увидела, как он сдал за последние годы, и, окончательно расчувствовавшись и тут же на себя за это рассердившись, вздёрнулась... (Л. Улицкая. Казус Кукоцкого) [Там же].

ЛСВ 'понимать интуитивно, осознавать' мотивационно объединяет 31 производную единицу. Дериваты с единственной мотивационной связью в этой группе слов отсутствуют.

С ЛСВ ‘быть способным к тонкому эстетическому восприятию’ соотносится единственный дериват - чувствительный, ср.: В каком-то смысле Кейс - PR-камертон, она всегда знает, что именно модно сейчас, что будет модно завтра и почему; она настолько чувствительна к стилю, что иногда ее физически тошнит при виде некоторых логотипов (А. Поляринов. Гибсон против Эллиса. Как «Гламорама» погубила) [Там же].

ЛСВ 'быть способным к пониманию другого' также мотивирует лишь одно производное - чувствование, ср.: Сочувствие не в том смысле, как мы в иколе проходили, а чувствование другого человека так же, как один палеи чувствует другой на руке, в общем-то (А. Клейн. Мир - это самое справедливое, что у нас есть) [Там же].

Обобщим далее сведения о тех компонентах СГ, которым свойственна семантическая корреляция с двумя или несколькими ЛСВ производящего глагола чувствовать. Соотносительность со всеми ЛСВ, кроме ЛСВ 'быть способным к тонкому эстетическому восприятию', коррелирующего с лексемой чувство, сохраняет только одно производное слово гнезда - синтаксический дериват чувствование. В значении прилагательного чувствительный и пяти его дериватов (чувствительно, чувствительность, нечувствительный, нечувствительно, нечувствительность) отражается семантика всех ЛСВ лексемы чувствовать, кроме ЛСВ 'быть способным к пониманию другого’.

С четырьмя ЛСВ, описывающими ситуации сенсорного восприятия, физического, эмоционального и ментального состояний, деривационно соотносится 6 производных (три элемента СП - nочувствовать, чувствоваться, чувствилище, а также три единицы СГ, соответствующие третьей-пятой ступеням деривации: почувствоваться, сверхчувствительный, сверхчувствительность). 
Все три ЛСВ, описывающие внутренние состояния, выступают в качестве мотивационной базы для существительного самочувствие, ср.: недостаток этих полезных веществ в организме может привести к болезням сердиа, нервозности, плохому самочувствию... (И вкусно, и полезно) [Там же]; Дело в том, что самое неприятное для психологического самочувствия - ощущать собственную беспомощность (А. Тхостов. Соблазн подмены понятий) [Там же]; Институт философии РАН на протяжении уже почти 20 лет ведёт всероссийский мониторинг социального самочувствия людей (А. Юревич. Тревожная стабилизация) [Там же].

Материалы Национального корпуса русского языка выявляют мотивационную связь прилагательного малочувствительный с тремя ЛСВ глагола чувствовать в другой комбинации - указывающих на сенсорное восприятие, эмоциональное состояние и ментальное состояние, ср. соответственно: Следовало только вовремя перестать посылать семена на одни и те же орбиты, поскольку это объект малочувствительный.... Вместо этого надо было продолжить ичитогенетическое изучение клеток первичных корешков, гораздо более чувствительных к радиаџии (Н. Делоне. У истоков космической генетики) [Там же]; ...nоложстельный и вообще малочувствительный профессор (что особенно хорошо знали студенты во время экзаменов) внезапно почувствовал себя несколько растроганнылм... (К. М. Станюкович. Жрецы) [Там же]; Впрочем, главное, что эти колхозы все-таки существуют и символизируют своего рода удар по капиталистическому способу мышления - малочувствительный, но удар (В. Пьецух. Весна в деревне) [Там же].

Двумя ЛСВ, описывающими эмоциональное и ментальное состояние, мотивировано шесть глагольных дериватов - восчувствовать, дочувствовать, вчувствоваться, очувствоваться, прочувствовать, предчувствовать, а также десять производных единиц, восходящих к последним трём, - вчувствование, прочувствование, прочувствованный, прочувствованно, прочувствованное, прочувствованность, прочувственный, прочувственно, предчувствоваться, предчувствие. Приведём примеры, иллюстрирующие семантику эмоционального состояния данных глаголов: Ты раскинь умом, вникни и восчувствуешь некоторую подлую тоску... (Д. Мамин-Сибиряк. Черты из жизни Пепко) [Там же]; И, если не дано мне творить, то хоть хочется дочитать, досмотреть, довидеть, дочувствовать настоящее (А. Эфрон. Письма Б. Л. Пастернаку) [Там же]; ...когда все ставится под вопрос, именно вдуматься, вчувствоваться, вглядеться в вопросы... (митрополит Антоний (Блум). Вопрошание и сомнение) [Там же]; Разнообразные фазисы празднества так непрерывно и быстро сменялись теперь один другим, что лицеисты, так сказать, очувствоваться не могли (В. П. Авенариус. Юношеские годы Пушкина) [Там же]; ... и дать прочувствовать свою огромную любовь к ней... (Письмо из зарубежья женщины сестре в Москву) [Там же]; ...и которые имели дар видеть свет и во тьме и предчувствовать радость будущего (Ф. Гладков. Повесть о детстве) [Там же].

В следующем блоке примеров объединены фрагменты текстов, в которых у глагольных дериватов актуализирована семантика ментального состояния, ср.: Каждый из нас знает и не раз восчувствовал мрачную систему замалчивания (Н. Рерих. Листы дневника) [Там же]; Пока дочувствовывала последнее слово, дочувствовать которого нельзя, ибо оно - душа, Брюсов, сухо щелкнув дверью, вышел (М. Цветаева. Герой труда) [Там же]; Его главная задача встрочться, вчувствоваться в логику шефа, в систему его придурей (В. Куренной. Агитпроп или самиздат) [Там же]; Этот горький и грозный упрек необходимо сльшиать великому русскому человеку, чтобы, так сказать, «опомниться», «очувствоваться» в понимании своих личных и общественных обязанностей (Г. Успенский. Горький упрек) [Там же]; Надо понять, прочувствовать всю сложннсть наших проблем (Д. Медведев. Россия, вперёд!) [Там же]; Он как бы предувствовал их опасность для государства, избегал встреч с западноевропейскими мыслителями (Д. Лихачев. О русской интеллигенции) [Там же].

Отдельного комментария требует лексема с деминутивным значением чувствованьице, представленная в словаре А. Н. Тихонова в СГ исходного слова чуять как дериват существительного чувствование. В современном русском языке данная лексема является устаревшей; её немногочисленные текстовые фиксации (в Национальном корпусе русского языка обнаружено лишь семь таких примеров) выявляют семантическую связь этого деминутива с синонимичным слову чувствование, но более простым структурно существительным чувство в значении 'внутреннее психическое состояние человека, его душевное переживание', ср.: Да наконеи, неужели для меня не прошла уже пора разжиганья своих всяких чувств и чувствованьиц? (В. Гаршин. Письма Н. М. Золотиловой) [Там же].

Сопоставив результаты анализа деривационного потенциала синонимов ощущать и чувствовать, приходим к следующим выводам:

1. Глагол чувствовать имеет более объёмную и сложную по структуре СП, чем его синоним ощущать. СП производящего слова чувствовать состоит из 14 элементов, образованных с помощью разных способов (префиксации, суффиксации, конфиксации, постфиксации и сложения). СП лексемы ощущать включает в себя лишь 5 дериватов, образованных путём суффиксации, префиксации и постфиксации. В соответствии с этим СП глагола чувствовать характеризуется значительно большим семантическим разнообразием, связанным с наличием в данной парадигме обширной глагольной зоны (10 ед.).

2. Осмысление результатов анализа СГ глаголов ощущать и чувствовать вкупе с контекстуальным анализом их производных компонентов позволяет упорядочить ЛСВ сопоставляемых синонимов по степени их деривационной продуктивности, используя принцип нисходящей градации, следующим образом: а) лексема ощущать: ЛСВ, описывающий ментальное состояние (21 ед.) > ЛСВ, описывающие чувственное восприятие (16 ед.), физическое (16 ед.) и эмоциональное состояния (16 ед.); б) глагол чувствовать: ЛСВ, описывающий эмоциональное состояние (37 ед.) > ЛСВ, описывающий ментальное состояние (31 ед.) > ЛСВ, 
описывающий сенсорное восприятие (23 ед.) > ЛСВ, описывающий физическое состояние (18 ед.) > ЛСВ, описывающие способность к эстетическому восприятию (1 ед.) и способность к пониманию другого (1 ед.).

Представляется важным констатировать факт специфической реализации словообразовательного потенциала, наблюдаемой у некоторых ЛСВ глаголов. Речь идёт о следующих индивидуальных корреляциях в СГ глагола ощущать: ЛСВ 'воспринимать органами чувств' - цветоощущение; ЛСВ 'понимать интуитивно' - жизнеочущение, мироощущение, предощущать, предощущаться и предощущение. В СГ глагола чувствовать больший деривационный потенциал демонстрируют также два компонента лексико-семантической парадигмы этого слова: ЛСВ 'воспринимать органами чувств' - пенициллиночувствительный, иветочувствительный, цвветочувствительность, высокочувствительный, радиочувствительность, светочувствительный, светочувствительность; ЛСВ ‘испытывать какое-л. эмоциональное или душевное состояние, чувство’ пречувствительный, пречувствительно, перечувствовать, перечувствоваться, расчувствоваться.

3. Глагол чувствовать обладает значительно большей деривационной продуктивностью, чем лексема ощущать (45 и 23 деривата в соответствующих СГ). В лексико-семантической парадигме глагола ощущать наивысшую деривационную продуктивность выявляет ЛСВ 'понимать интуитивно' (большинство из соотносящихся с этим ЛСВ дериватов - имена существительные), тогда как у слова чувствовать по количеству дериватов, преимущественно глагольных, доминирует ЛСВ 'испытывать какое-л. эмоциональное, душевное состояние, чувство'.

Полученные данные свидетельствуют о более высоком функциональном потенциале глагола чувствовать в сравнении с его синонимом ощущзать и, соответственно, более значимой позиции этого слова в ментальном лексиконе носителей русского языка. Сопоставление этих слов сквозь призму русской языковой картины мира - основная перспектива наших дальнейших исследований.

\title{
Список источников
}

1. Го Л. Функционально-семантическая специфика глагола чувствовать // Перевод. Язык. Культура: IX Междунар. науч.-практ. конф. (25 мая 2018 г.) / отв. ред. Л. В. Коцюбинская. СПб.: ЛГУ им. А. С. Пушкина, 2018. С. 18-22.

2. Го Л., Косова В. А. Глагол ощущать: опыт семантико-когнитивного анализа // Филология и культура. Philology and culture. 2018. № 1 (51). C. 42-48.

3. Динамика семантико-словообразовательных подсистем русского языка: коллективная монография / под ред. проф. О. И. Дмитриевой. Саратов: Научная книга, 2010. 370 с.

4. Ефремова Т. Ф. Новый толково-словообразовательный словарь русского языка [Электронный ресypc]. URL: https://efremova. slovaronline.com/ (дата обращения: 07.11.2019).

5. Ефремова Т. Ф. Толковый словарь словообразовательных единиц русского языка: ок. 1900 словообразов. единиц. Изд-е 2-е, испр. М.: АСТ; Астрель, 2005. 636 с.

6. Кацнельсон С. Д. Содержание слова, значение и обозначение. М. - Л.: Наука, 1965. 110 с.

7. Косова В. А. Системная значимость словообразовательных категорий в русском языке: автореф. дисс. ... д. филол. н. Казань, 2014. 43 с.

8. Маслов Ю. С. Очерки по аспектологии. Л.: ЛГУ, 1984. 263 с.

9. Национальный корпус русского языка [Электронный ресурc]. URL: http://www.ruscorpora.ru/ (дата обращения: 07.11.2019)

10. Обзор работ по современному русскому литературному языку за 1974-1977 гг.: словообразование: материалы для обсуждения / под ред. В. В. Иванова. М.: Наука, 1982. 151 с.

11. Русский древослов. Историко-словообразовательный словарь русского языка [Электронный ресурс]. URL: http://www.drevoslov.ru/ (дата обращения: 07.11.2019).

12. Русский семантический словарь: в 6-ти т. / под ред. Н. Ю. Шведовой. М.: Азбуковник, 1998. Т. 4. Глагол. 924 с.

13. Семантические вопросы словообразования: значение производящего слова / под ред. М. Н. Янценецкой. Томск: Изд-во Том. ун-та, 1991. $271 \mathrm{c.}$

14. Словарь русского языка: в 4-х т. / гл. ред. А. П. Евгеньева. М.: Рус. яз., 1985. Т. 1. А - Й. 696 с.; 1986. Т. 2. К - О. 736 с.; 1987. Т. 3. П- Р. 752 с.; 1988. Т. 4. С-Я. 800 c.

15. Тихонов А. Н. Словообразовательный словарь русского языка: в 2-х т. М.: АСТ; Астрель, 2008. Т. 1. 860 с.; Т. 2.941 с.

\section{Derivational Potential of Synonymous Verbs Ощущать (Perceive) and Чувствовать (Feel): Comparative Analysis}

\author{
Guo Lin \\ Kazan (Volga Region) Federal University \\ guolin315@mail.ru
}

The article is devoted to the problem of functional differentiation of synonymous deictic verbs ouyщamb (to perceive) and чувствовать (to feel). Comparison of their word-formative clusters and contextual analysis of speech usage of their derivatives allowed the researcher to identify correlation of lexico-semantic variants and derivatives. The conclusion is made about higher word-formative potential of the second lexeme ( 23 and 45 derivatives correspondingly). It is shown that among derivatives of the verb чувствовать, words with the meaning "experience emotional state" prevail, whereas the meaning "understand intuitively" is most frequent among derivatives of the verb ouyщamb.

Key words and phrases: lexical synonyms; word-formative paradigm; word-formative cluster; derivational potential; lexicosemantic variant. 